\title{
Pelatihan dan Pendampingan Perawatan Alat Produksi Pada Usaha Mikro Kerupuk Samiler
}

\author{
Training and Assistance for the Maintenance of Production Tools in the Samiler \\ Crackers Micro Business
}

\author{
Achmad Rijanto ${ }^{1}$, Suesthi Rahayuningsih ${ }^{2}$ \\ ${ }^{1}$ Program Studi Teknik Mesin, Fakultas Teknik, Universitas Islam Majapahit, Indonesia \\ ${ }^{2}$ Program Studi Pendidikan Matematika, Fakultas Keguruan dan Ilmu Pendidikan, Universitas Islam \\ Majapahit, Indonesia \\ e-mail: ${ }^{1}$ rijanto1970@gmail.com, ${ }^{2}$ esthiachmad@gmail.com
}

\begin{abstract}
Abstrak
Pengabdian kepada masyarakat ini dilaksanakan di desa Kemasantani, Gondang, Mojokerto dengan mitra pengusaha mikro kerupuk samiler. Mitra mempunyai permasalahan yaitu kurangnya pengetahuan dan ketrampilan tentang perawatan alat produksi mesin parut dengan bahan bakar gas. Mesin ini merupakan teknologi baru yang digunakan dalam proses produksinya. Solusi terhadap masalah ini adalah memberikan pemahaman tentang pengetahuan dan ketrampilan tentang perawatan alat produksi tersebut. Pengabdian ini bertujuan meningkatkan pengetahuan dan ketrampilan mitra tentang perawatan alat produksi mesin parut dengan bahan bakar gas, sehingga mesin dapat awet dan bertahan lama. Pengabdian ini menggunakan metode pelatihan dan pendampingan kepada pengusaha mikro kerupuk samiler. Hasil capaian pengabdian ini adalah meningkatnya pengetahuan mitra sebesar $40 \%$ dan ketrampilan 55\% untuk perawatan alat produksi mesin parut dengan bahan bakar gas.
\end{abstract}

Kata Kunci: pelatihan, pendampingan, perawatan, alat produksi, usaha mikro kerupuk samiler

\begin{abstract}
This community service was carried out in the village of Kemasantani, Gondang, Mojokerto with the micro cracker samiler business partner. Partners have a problem, namely a lack of knowledge and skills regarding maintenance of gas-fired grater production equipment. This machine was a new technology used in the production process. The solution to this problem was to provide an understanding of the knowledge and skills regarding the maintenance of these production tools. This dedication aims to increase the knowledge and skills of partners regarding the maintenance of gas-fired grater production tools, so that the engine can last a long time. This service used training and mentoring methods for micro-cracker samiler entrepreneurs. The result of this dedication was an increase in partner knowledge by $40 \%$ and skills by 55\% for the maintenance of gas-fired grating machine production tools.

Keyword: training, mentoring, maintenance, production equipment, samiler cracker micro business
\end{abstract}

\section{PENDAHULUAN}

Usaha mikro merupakan salah satu penopang kehidupan ekonomi yang berbasis masyarakat menengah ke bawah. Kegiatan usaha mikro di desa Kemasantani kabupaten Mojokerto, dalam bidang produksi terutama usaha produksi kerupuk samiler sudah berkembang di masyarakat setempat. Dari hasil wawancara dan observasi di lokasi tim pelaksana kegiatan pengabdian masyarakat, diperoleh informasi bahwa pengusaha mikro kerupuk samiler mempunyai masalah, yaitu kurangnya pengetahuan dan ketrampilan tentang perawatan alat produksi mesin parut singkong dengan bahan bakar gas. Mesin ini merupakan hasil pemberian atau hibah dari kegiatan pengabdian masyarakat. Mesin ini berfungsi untuk memarut bahan baku berupa singkong yang masih mentah dan baru dikupas. Semula, mesin yang digunakan (mesin lama) bersumber tenaga listrik dan kondisinya sudah rusak. Sedangkan mesin parut yang baru mesin parut berbahan bakar gas. Mesin ini digunakan sebagai upaya pengusaha mikro untuk penghematan biaya produksi. Pada gambar 1a dapat dilihat kegiatan wawancara dan observasi tim pelaksana pengabdian 
dengan penusaha mikro dan gambar $1 \mathrm{~b}$ mesin parut singkong lama yang digunakan pengusaha mikro serta gambar 1c mesin parut singkong baru berupa mesin parut dengan bahan bakar gas.

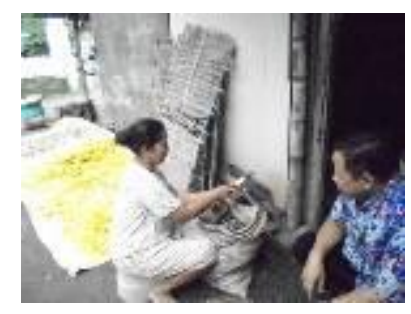

(a)

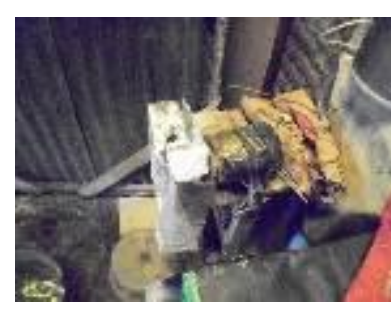

(b)

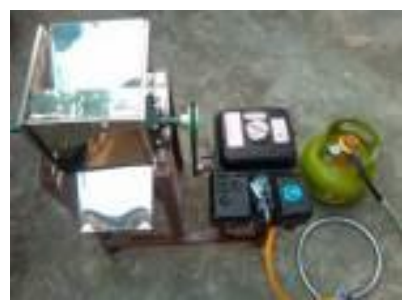

(c)

Gambar 1: (a) Wawancara pelaksana dengan pengusaha mikro (b) mesin parut lama (c) mesin parut baru (sumber: dokumentasi tim pelaksana)

Berdasarkan permasalahan di atas tim mengadakan pengabdian kepada pengusaha mikro ini bertujuan untuk meningkatkan pengetahuan dan ketrampilan pengusaha mikro khususnya pada perawatan mesin parut singkong dengan bahan bakar gas. Usaha dalam rangka meningkatkan pengetahuan dan ketrampilan ini, solusi yang ditawarkan kepada mitra pengusaha mikro ini adalah memberikan pelatihan dan pendampingan tentang perawatan mesin parut singkong dengan menggunakan bahan bakar gas, baik secara teori maupun praktik.

Pemberian pelatihan dan pendampingan tentang perawatan mesin parut dengan menggunakan bakar gas ini, diharapkan dapat memecahkan masalah yang dihadapi pengusaha mikro ini, yaitu kurangnya pengetahuan dan ketrampilan merawat alat produksi mesin parut singkong dengan bahan bakar gas. Peningkatan sumber daya manusia dapat dilakukan ditingkatkan melalui pelatihan. (Santoso, 2010), menyampaikan bahwa metode pelatihan lebih banyak menekankan pada proses pembelajaran praktisi daripada teori. Metode ini digunakan untuk meningkatkan kemampuan dalam satu atau beberapa jenis ketrampilan pada pengusaha mikro. (Aditya, 2015), mengemukakan dari hasil penelitian menunjukkan bahwa pelatihan kerja yang diberikan kepada karyawan akan berdampak positif terhadap kinerja karyawan. Sebagai bukti adanya pengaruh yang besar pelatihan kerja terhadap peningkatan kompetensi karyawan yaitu sebesar 71,9\%. Pelatihan usaha sablon plastik dapat mengurangi biaya produksi, sehingga pendapatan keuangan bertambah. Selain itu pelatihan kepada Usaha Mikro Kecil dan Menengah (UMKM) tentang manajemen usaha dan strategi pemasaran produk dapat menigkatkan keilmuan dan ketrampilan pengusaha (Rujianto, 2015). Pendampingan menurut (Maryani et al., 2018), bahwa metode yang efektif untuk menambah motivasi berusaha yaitu melalui pendampingan kelompok usaha. Pendampingan yang baik dapat menciptakan suasana kondusif untuk belajar dan saling memotivasi sesama wirausaha.

Peningkatan UMKM juga dapat dicapai melalui penambahan jaringan pemasaran, modal dan sarana prasarana. Peningkatan UMKM menurut (Anggraeni, 2013), yaitu dengan meningkatkan potensi diri dari pendanaan awal berasal tabungan sendiri. Setelah itu memperluas jaringan pemasaran dan meningkatkan sarana dan prasarana. Usaha ini dilakukan pada kelompok usaha emping jagung. Sedangkan (Alyas, 2017), menyatakan bahwa pengembangan usaha kecil dapat dilakukan dengan pengembangan pasar dan produk dalam penguatan ekonomi usaha kecil, contohnya pada usaha roti maros. Sedangkan pelatihan dan pendampingan peningkatan pengelolaan usaha dapat meningkatkan kapasitas produksi usaha keripik singkong melalui peningkatan teknologi alat produksi, yaitu dari teknologi alat perajang keripik jenis translasi menjadi rotasi. Alat ini dapat meningkatkan kapasitas perajangan keripik singkong menjadi 4 kali lipat (Rijanto, A., \& Rahayuningsih, 2019b). 
Dengan adanya kegiatan pengabdian masyarakat kepada pengusaha mikro kerupuk samiler ini, diharapkan dapat memberikan manfaat dan hasil yang besar bagi pengusaha mikro ini. Adanya peningkatan pengetahuan dan ketrampilan tentang perawatan alat produksi mesin parut dengan bahan bakar gas, maka pengusaha mikro kerupuk samiler dapat menghemat biaya produksi dari biaya penggantian alat produksi. Perawatan alat produksi yang baik dapat memperpanjang umur alat, karena resiko kerusakan alat lebih kecil, sehingga alat produksi menjadi awet dan tahan lama.

\section{METODE PELAKSANAAN}

Pengabdian ini berlokasi di di desa Kemasantani, Mojokerto, Provinsi Jawa Timur. Sebagai mitra sasaran adalah pengusaha mikro kerupuk samiler, ibu Yani. Lokasi desa ini tidak jauh dari Universitas Islam Majapahit (UNIM), yaitu berjarak kurang lebih $18 \mathrm{~km}$ ke arah selatan UNIM. Usaha mitra pengabdian termasuk jenisusaha mikro, karena berdasarkan Keputusan Menteri Keuangan No.40/KMK.06/2003 tanggal 29 Januari 2003 tentang pendanaan kredit usaha mikro dan kecil, bahwa usaha mikro adalah usaha produktif milik keluarga atau perorangan Warga Negara Indonesia dan memiliki hasil penjualan paling banyak Rp.100.000.000,00 (seratus juta rupiah) per tahun. Usaha Mikro dapat mengajukan kredit kepada bank paling banyak Rp.50.000.000,- (Kemenkeu, 2003). Pengertian usaha mikro menurut Undang-Undang No. 20 tahun 2008 tentang UMKM yaitu usaha mikro adalah usaha produktif milik orang perorang dan atau badan usaha perorangan yang memenuhi kriteria usaha mikro, memiliki kekayaan bersih paling banyak Rp 50.000.000 (lima puluh juta rupiah) tidak termasuk tanah dan bangunan tempat usaha; atau memiliki hasil penjualan tahunan paling banyak Rp. 300.000.000,00 (tiga ratus juta rupiah) (Undang-Undang, 2008).

Tahapan pelaksanaan pengabdian masyarakat yang dilakukan meliputi langkah-langkah sebagai berikut: Pertama tim pelaksana pengabdian melakukan analisis situasi pada mitra pengabdian di desa Kemasantani. Dari observasi lapangan dan wawancara tim dengan mitra pengusaha mikro kerupuk samiler, tim pelaksana memperoleh banyak permasalahan yang dialami oleh pengusaha mikro. Lalu tim dan mitra pengabdian merumuskan permasalahan yang akan diatasi, yaitu pengetahuan dan ketrampilan mitra masih kurang tentang perawatan alat produksi berupa mesin parut singkong dengan bahan bakar gas. Setelah itu tim menawarkan solusi untuk mengatasi permasalahan mitra, yaitu akan meningkatkan pengetahuan dan ketrampilan perawatan mesin parut singkong dengan bahan bakar gas. Peningkatan pengetahuan dan ketrampilan akan dilakukan dengan metode pelatihan dan pendampingan. Sebelum pelaksanaan pelatihan dan pendampingan mitra akan diberikan pre tes tentang pengetahuan dan ketrampilan tentang perawatan mesin parut berbahan bakar gas. Hal ini sebagai upaya untuk mengukur pengetahuan dan ketrampilan mitra tentang perawatan mesin parut singkong dengan bahan bakar gas. Pada saat pelatihan mitra akan diberikan materi baik secara teori ataupun praktek. Pendampingan akan dilakukan kepada mitra terutama pada saat melakukan praktik. Seusai pelatihan dan pendampingan akan dilakukan pos tes kepada mitra, untuk mengukur pengetahuan dan ketrampilan yang diperoleh setelah mengikuti pelatihan dan pendampingan. Analisis data tentang tingkat pengetahuan dan ketrampilan mitra, dilakukan setelah data yang diperoleh selama mengikuti pelatihan dan pendampingan terkumpul. Dari analisis data yang telah telah diperoleh, maka dapat diambil kesimpulan tentang seberapa besar adanya peningkatan pengetahuan dan ketrampilan mitra tentang perawatan alat produksi berupa mesin parut singkong dengan bahan bakar gas. Diagram alir tahapan pelaksanaan kegiatan pengabdian kepada masyarakat ini terlihat pada gambar 2. 


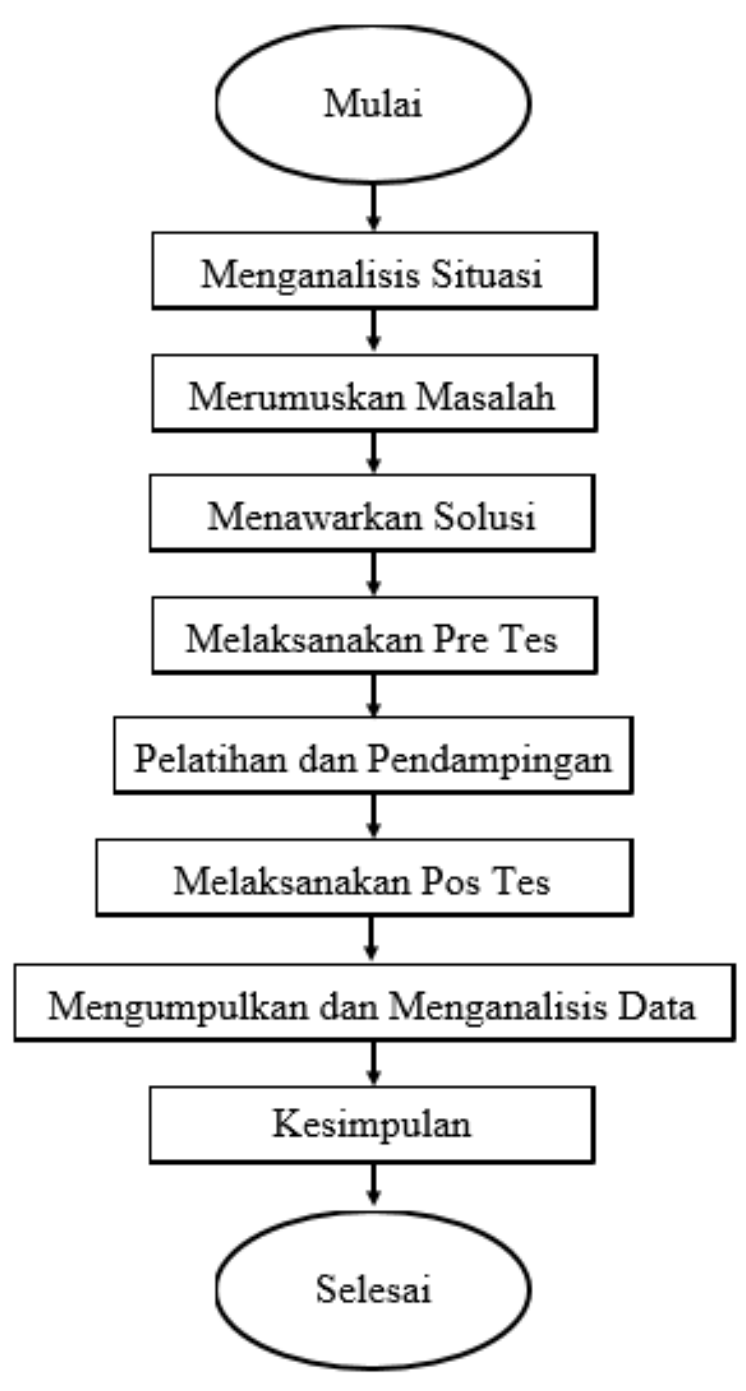

Gambar 2. Diagram alir kegiatan pelaksanaan pengabdian kepada masyarakat

Sebagai indikator tingkat keberhasilan kegiatan pengabdian ini, yaitu dapat dilihat jika permasalahan yang dihadapi oleh mitra teratasi. Dalam artian, bahwa dengan adanya kegiatan pengabdian berupa pelatihan dan pendampingan kepada mitra ini, maka pengetahuan dan ketrampilan mitra untuk merawat alat produksi berupa mesin parut singkong dengan bahan bakar gas meningkat, sehingga mitra dapat merawat sendiri alat produksinya dengan baik.

\section{HASIL DAN PEMBAHASAN}

Dalam upaya untuk meningkatkan pengetahuan dan ketrampilan mitra pengabdian tentang perawatan alat produksi mesin parut singkong dengan bahan bakar gas, maka tim mengadakan pelatihan dan pendampingan kepada mitra. Materi yang disampaikan terdiri dari materi perawatan secara berkala dan materi perawatan perkomponen alat produksi. Materi perawatan secara berkala meliputi materi perawatan harian, mingguan, bulanan dan tahunan. Sedangkan materi perawatan perkomponen antara lain cara membesihkan saringan udara, cara melepas dan membersihkan busi, cara mengganti oli mesin cara melepas dan mengganti pully, cara membersihkan dan melepas mata parut, cara melumasi bearing pada mesin dan lain-lain. Materi disampaikan baik secara teori maupun praktik. 
Untuk mengukur ketercapaian keberhasilan atas pemahaman materi pelatihan dan pendampingan, maka sebelum pelaksanaaan dilakukan tes (pre tes) dan setelah pelatihan dan pendampingan dilakukan tes juga (pos tes). Data hasil akhir pre tes dan pos tes yang telah dilakukan terlihat pada tabel 1 dan dalam bentuk grafik pada gambar 3.

Tabel 1. Pre Tes dan Pos Tes Pelatihan dan Pendampingan

\begin{tabular}{clcccc}
\hline \multirow{2}{*}{ No } & Materi pelatihan & \multicolumn{3}{c}{ Nilai } & Peningkatan \\
\cline { 3 - 5 } & & Pre-tes & post-tes & Peningkatan & $(\boldsymbol{\%})$ \\
\hline 1 & Teori & 40 & 80 & 40 & $40 \%$ \\
\hline 2 & Praktek & 30 & 85 & 55 & $55 \%$ \\
\hline
\end{tabular}

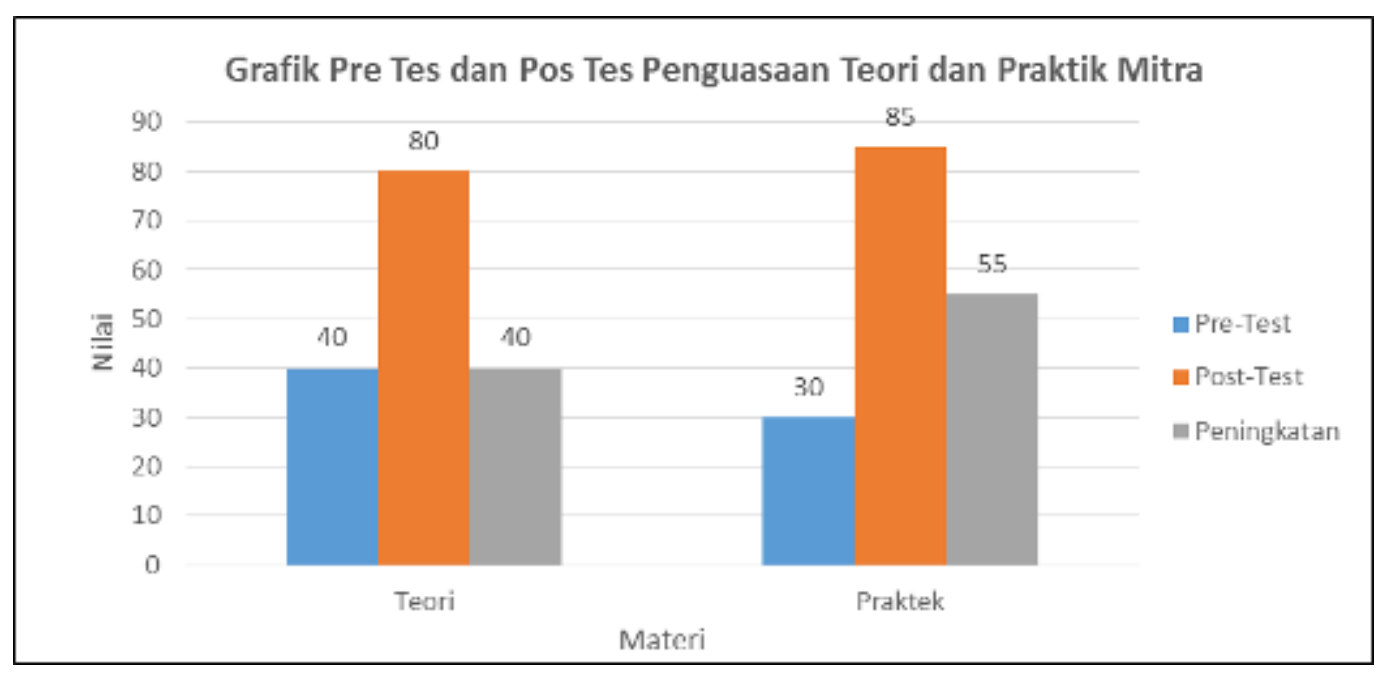

Gambar 3. Grafik Pre Tes dan Pos Tes Penguasaan Materi Teori dan Praktik

Berdasarkan tabel 1 dan gambar 3 di atas, terlihat bahwa pada awal tes (pre tes) terlihat bahwa pengetahuan mitra tentang teori perawatan mesin parut singkong dengan bahan bakar gas memperoleh nilai 40 dan ketrampilan mitra tentang praktik sebesar 30. Hal ini menunjukkan, bahwa perawatan alat produksi tersebut merupakan hal yang baru bagi mitra. Dengan tingkat pengetahuan dan ketrampilan sebesar itu, mitra akan mengalami kesulitan untuk melaksanakan perawatan terhadap alat produksinya. Diharapkan dengan adanya pelatihan dan pendampingan yang telah diikuti mitra, dapat meningkatkan pengetahuan dan ketrampilan mitra pengabdian.

Dari tabel 1 dan gambar 3 juga terlihat hasil tes akhir yang dilakukan setelah pelatihan dan pendampingan (pos tes). Setelah pelatihan nilai pengetahuan mitra menjadi 80, sedangkan nilai ketrampilan mitra menjadi 85 . Hal ini menunjukkan, bahwa setelah mitra mengikuti pelatihan dan pendampingan dalam kegiatan pengabdian kepada masyarakat ini, tingkat pengetahuan mitra meningkat sebesar $40 \%$, sedangkan tingkat ketrampilan mitra nmeningkat sebesar 55\%. Peningkatan ketrampilan lebih tinggi dibanding peningkatan pengetahuan. Hal ini dikarenakan pada saat awal tes nilai ketrampilan lebih rendah dibanding dengan nilai pengetahuan yang dimiliki mitra. Disamping itu pada saat pelatihan dan pendampingan mitra lebih tertarik pada praktek dari pada teori, sehingga nilai akhir untuk praktek lebih besar dibanding nilai teori. Peningkatan ini terjadi dikarenakan materi teori dan praktik yang diberikan dengan metode pelatihan dan pendampingan ini, dapat membantu mitra untuk lebih cepat memahami materi yang telah diberikan. Disamping itu materi perawatan alat produksi berupa mesin parut singkong dengan bahan bakar gas ini dibuat lebih sederhana, agar lebih cepat dipahami oleh mitra. Dari kegiatan pengabdian yang lain tentang metode pelatihan dan 
pendampingan ini, menurut (Rijanto, A., \& Rahayuningsih, 2019a), menyatakan bahwa pelatihan dan pendampingan pengelolaan usaha mikro dapat menambah pengetahuan tentang surat ijin usaha mikro (SIUM) sebesar 50\%, peningkatan pengetahuan pembuatan pembukuan keuangan sederhana sebesar $30 \%$ dan pengetahuan tentang pengoperasian alat produksi sebesar 40\%. Sedangkan (Suhendri, 2015), menyatakan bahwa pelatihan dan pendampingan mitra pada usaha dapat meningkatkan kesejahteraan, karena pendapat usaha mikro meningkat. Jika kesejahteraan pengusaha mikro meningkat, maka kesejahteraan masyarakat meningkat pula. Dari kegiatan pelatihan dan pendampingan yang telah dilakukan menunjukkan adanya peningkatan pengetahuan dan ketrampilan mitra tentang perawatan alat produksi berupa mesin parut singkong dengan bahan bakar gas.

Kegiatan pelatihan dan pedampingan dilalukan di rumah mitra pengabdian, di desa kemasantani, kabupaten Mojokerto. Kegiatan pengabdian masyarakat kepada mitra pengusaha mikro kerupuk semiler ini terlihat pada gambar 4.

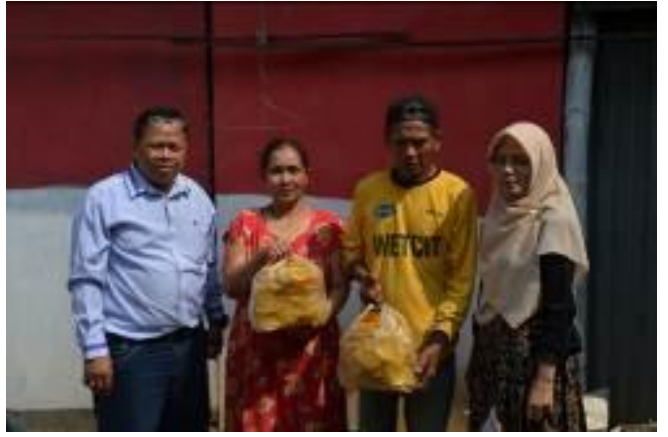

(a)

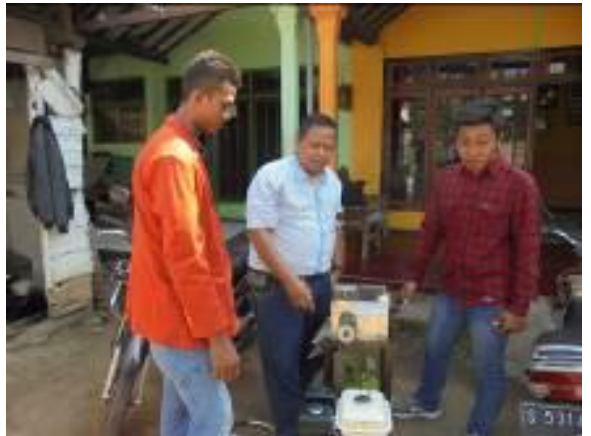

(b)

Gambar 4. Pelaksanaan pengabdian (a) Tim bersama Mitra (b) Tim mempraktikkan alat

\section{KESIMPULAN}

Berdasarkan hasil analisis dan pembahasan terhadap kegiatan pengabdian masyarakat yang telah dilakukan dapat disimpulkan bahwa setelah pelaksanaan pelatihan dan pendampingan kepada mitra tentang perawatan alat produksi berupa mesin parut singkong dengan bahan bakar gas, maka kegiatan ini menghasilkan adanya peningkatan pengetahuan atau teori mitra sebesar $40 \%$ dan ketrampilan atau praktik $55 \%$.

\section{DAFTAR PUSTAKA}

Aditya, R. (2015). PENGARUH PELATIHAN TERHADAP KOMPETENSI DAN KINERJA KARYAWAN (Studi Pada Karyawan PT. PLN (Persero) Distribusi Jawa Timur Area Malang). Jurnal Administrasi Bisnis S1 Universitas Brawijaya, 27(2), 1-6.

Alyas, M. R. (2017). Strategi Pengembangan Usaha Mikro, Kecil Dan Menengah Dalam Penguatan Ekonomi Kerakyatan (Studi Kasus Pada Usaha Roti Maros Di Kabupaten Maros). Sosiohumaniora, 19(2), 114-120.

Anggraeni, F. (2013). Pengembangan Usaha Mikro, Kecil Dan Menengah (UMKM) Melalui

Fasilitasi Pihak Eksternal Dan Potensi Internal (Studi Kasus Pada Kelompok Usaha

"Emping Jagung" Di Kelurahan Pandanwangi Kecamatan Blimbing Kota Malang). Jurnal Administrasi Publik Mahasiswa Universitas Brawijaya, 1(6), 1286-1295.

Kemenkeu. (2003). Keputusan Menteri Keuangan Republik Indonesia No. 40/KMK.06/2003, Tentang Pendanaan Kredit Usaha Mikro Dan Kecil.

Maryani, I., Mustofa, A., \& Septian Emma Dwi, J. (2018). Efektivitas Pendampingan 
Kelompok Dalam Meningkatkan Motivasi Berwirausaha Peternak Sapi Perah. JPPM (Jurnal Pengabdian Dan Pemberdayaan Masyarakat), 2(1), 7-13.

Rijanto, A., \& Rahayuningsih, S. (2019a). Pelatihan Dan Pendampingan Pengusaha Mikro Kerupuk Samiler Dalam Upaya Meningkatkan Pengetahuan Pengelolaan Usaha Mikro. Prosiding SNasPPM, 217-222.

Rijanto, A., \& Rahayuningsih, S. (2019b). PKM Peningkatan Pengetahuan Pengelolaan Usaha Pada Pengusaha Mikro Keripik Singkong. Prosiding Seminar Nasional Penelitian Dan Pengabdian (SNP2M). Universitas Islam Majapahit, 7-12.

Rujianto, J. P. (2015). IbM Pengembangan UKM Krupuk Wedi Dan Kacang Tanah Kulit Dengan Mesin Otomatis Di Desa Wedelan Kecamatan Bangsri Kabupaten Jepara. ITEKS, $7(1)$.

Santoso, B. (2010). Skema dan Mekanisme Pelatihan: Panduan Penyelenggaraan Pelatihan.

Suhendri, H. (2015). Pelatihan dan Pendampingan Usaha Mikro Dhi Sablon \& Printing dan The Joker's Sablon \& Offset di Malang. Jurnal Dedikasi, 12(1), 8-13.

Undang-Undang. (2008). Undang-undang nomor 20 tahun 2008 tentang Usaha Mikro, Kecil dan Menengah. 